\title{
An Optical Based Biosensor for the Determination of Ammonium in Aqueous Environment
}

\author{
Nur Ellina Azmi ${ }^{1}$, Jaafar Abdullah ${ }^{1 *}$, Musa Ahmad ${ }^{2}$, Hamidah Sidek ${ }^{1}$, \\ Lee Yook Heng ${ }^{2}$, Samsulida Abd Rahman ${ }^{1}$ \\ ${ }^{1}$ Industrial Biotechnology Research Centre, SIRIM Berhad, Shah Alam, Malaysia \\ ${ }^{2}$ School of Chemical Sciences and Food Technology, Faculty of Sciences and Technology, \\ Universiti Kebangsaan Malaysia, Bangi, Malaysia \\ Email: *jaafar@sirim.my
}

Received February 13, 2012; revised March 15, 2012; accepted March 25, 2012

\begin{abstract}
A simple and rapid optical biosensor for the determination of ammonium was developed by immobilization of glutamate dehydrogenase (GLDH) and diaphorase (Dph) in chitosan film coated on a glass slide employing thiazolyl blue tetrazolium bromide (MTT) as a color indicator. The developed biosensor displays a purple color formation of formazan attributed to the unreacted NADH in the reaction system in the presence of ammonium. The color intensity was found to decrease proportionally with the increase of ammonium concentrations after $10 \mathrm{~min}$ exposure. The linearity of the biosensor towards ammonium was in the range of $16.8-70 \mu \mathrm{M}\left(\mathrm{R}^{2}=0.9955\right)$ with detection limit of $11 \mu \mathrm{M}$. A good agreement $\left(\mathrm{R}^{2}=0.9984\right)$ with indothymol method was obtained in the measurement of fish pond water samples. The effect of potential interferences such as metals ion has also been evaluated.
\end{abstract}

Keywords: Optical Biosensor; Glutamate Dehydrogenase; Diaphorase; Ammonium

\section{Introduction}

The determination of ammonia $\left(\mathrm{NH}_{3}\right)$ in the environmental samples has become increasingly important. Usually, ammonia exist either in form of gases as ammonia or in water as ammonium $\left(\mathrm{NH}_{4}^{+}\right)$ions [1]. Ammonia is part of the natural nitrogen cycle and it is released to the environment by natural processes such as the decomposition of organic matter, human and animal excrements, or by volcanic eruptions [2]. It can also be distributed to the environment by activities like extensive use of fertilizers, spillage or leakage from wastewater treatment plants [3]. Ammonia is often found at low level in natural water however, elevated concentration of this compound can occur usually due to effluent discharges from sewage treatment plants, industrial processes or farming activeties $[2,3]$.

Various approaches have been developed to detect dissolved ammonia in aqueous environment employing either electrochemical or optical methods [4-6]. These methods are time consuming and often require skill personnel to operate the sample preparation. An interesting alternative method for determination of dissolved ammonia involves the development of biosensors, which can offer simple, rapid, sensitive, specific and portable sys-

${ }^{*}$ Corresponding author. tem $[2,3,7]$.

Several papers have been published on the determination of dissolved ammonia employing enzyme system. The reaction involved the use of enzyme glutamate dehydrogenase (GLDH), which requires the cofactor $\beta$ nicotinamide adenine dinucleotide (NADH) and ammonium $\left(\mathrm{NH}_{4}^{+}\right)$in the enzymatic conversion of 2-oxoglutarate to L-glutamate [8-10]. During the reaction NADH is oxidized to $\mathrm{NAD}^{+}$, thereby making possible the indirect monitoring of ammonium by measuring the consumption of NADH either amperometrically at a potential of $+0.76 \mathrm{~V}$ or optically at a wavelength of $340 \mathrm{~nm}$. There are some intricacy present in the amperometric detection of NADH like the involvement high overpotentials and the formation of by-products that caused the adsorption of (NAD) $)_{2}$ dimers which foul the electrode surface $[11,12]$. Optical sensors have attracted the attention of many researches because of their small size, ease of operation and freedom from electrical interference [13].

Here, we demonstrate a colorimetric based biosensor employing stacked film immobilization of glutamate dehydrogenase (GLDH) and diaphorase (Dph) in combination with redox indicator thiazolyl blue tetrazolium bromide (MTT) for the determination of ammonium ion in aqueous environment. The biosensor offer several advantages including the ability of the sensors to give a 
quick indication on the presence of analyte of interest based on the color changes by using dual enzymes.

\section{Experimental}

\subsection{Reagents}

Dph, NADH, MTT, copper chloride, ferrous sulphate, zinc chloride, silver nitrate, mercury chloride, calcium chloride, potassium chloride and sodium nitrate were purchased from SIGMA. GLDH and $\alpha$-ketoglutaric acid were obtained from FLUKA. Chitosan and sodium nitroprusside were supplied by Chito-Chem (M) Sdn. Bhd. and Merck, respectively. Thymol was acquired from BDH Chemicals. Sodium hypochlorite $10 \%$ was acquired from Systerm and ammonium chloride was purchased from R \& M Marketing. All chemicals were of analytical grades and used without further purification.

\subsection{Preparation of Biosensor}

Chitosan solution (2\%) was prepared by dissolving $2.0 \mathrm{~g}$ chitosan powder in $100 \mathrm{~mL}$ acetic acid $(1 \%, \mathrm{v} / \mathrm{v})$. The viscous solution was stirred overnight at room temperature. GLDH (40 mg/mL) and Dph $(40 \mathrm{mg} / \mathrm{mL})$ stock solution were prepared by dissolving $0.012 \mathrm{~g}$ of respective GLDH powder and Dph powder in $300 \mu \mathrm{L}$ of 50 $\mathrm{mM}$ phosphate buffer solution $\mathrm{pH}$ 7. These solutions were then divided into $20 \mu \mathrm{L}$ aliquots and kept at $-20^{\circ} \mathrm{C}$ for later use. A homogeneous stock solution of GLDH/ chitosan mixture was prepared by mixing GLDH solution $(40 \mathrm{mg} / \mathrm{mL})$ and chitosan solution $(2 \%)$ at a volume ratio of 0.25 to $1.0(\mathrm{v} / \mathrm{v})$. Dph/chitosan mixture was prepared by using the same ratio as the latter.

Figure 1(a) illustrates the enzyme immobilization process: $10 \mu \mathrm{L}$ of the Dph/chitosan mixture was deposited onto a glass slide in an area of $9 \mathrm{~mm} \times 10 \mathrm{~mm}$. Then it was spun at $2000 \mathrm{rpm}$ for $3 \mathrm{~s}$. The biosensor was kept at $4^{\circ} \mathrm{C}$ for drying. A volume of $10 \mu \mathrm{L}$ of the $\mathrm{GLDH} /$ chitosan mixture was then pipetted onto the dried film of Dph/chitosan on a glass slide and coated gently over an area of $9 \mathrm{~mm} \times 10 \mathrm{~mm}$. Again, it was spun at $2000 \mathrm{rpm}$ for $3 \mathrm{~s}$ and dried at $4^{\circ} \mathrm{C}$.

\subsection{Evaluation of Biosensor Response}

All absorption measurements were conducted by using an ultraviolet-visible spectrophotometer (Varian Cary 50). The biosensor was soaked in $50 \mathrm{mM}$ phosphate buffer solution $\mathrm{pH} 8.0$ for $5 \mathrm{~min}$ to remove unbound enzyme and then it was washed with distilled water. It was then exposed to $3 \mathrm{~mL}$ of $50 \mathrm{mM}$ phosphate buffer solution $\mathrm{pH}$ 8.0 consisting of ammonium $(1 \mathrm{mM}), \alpha$-ketoglutaric acid (0.15 mM), NADH $(0.15 \mathrm{mM})$ and MTT $(0.3 \mathrm{mM})$ for $10 \mathrm{~min}$ reaction time as shown in Figure 1(b). The response of the biosensor was studied at a fixed wave- length of $565 \mathrm{~nm}$ as described in Equation (1).

$$
\Delta \operatorname{Abs}(565 \mathrm{~nm})=\mathrm{I}_{10 \min }-\mathrm{I}_{0} \min
$$

$\mathrm{I}_{0 \text { min }}$ and $\mathrm{I}_{10 \text { min }}$ are absorption intensity of the biosensor film at $0 \mathrm{~min}$ and $10 \mathrm{~min}$ of reaction time, respectively.

\subsection{Comparison of the Biosensor Response and Analysis of Spiked Real Samples}

The response of the biosensor to various concentrations of ammonium ion $(0.0-0.15 \mathrm{mM})$ was compared via indothymol method [14]. For indothymol, the reaction was based on ammonium ion solution reacts with nitroprusside $(0.017 \mathrm{M})$, sodium hypochlorite $(0.013 \%)$ and thymol $(0.027 \mathrm{mM})$ at $\mathrm{pH} 10.0$ to form a blue color. The absorption was measured after $5 \mathrm{~min}$ at a wavelength of $690 \mathrm{~nm}$.

For the evaluation of the biosensor performance with real samples, water samples obtained from four fish ponds were used for the analysis. The water samples were adjusted to $\mathrm{pH} 8.0$ with $50 \mathrm{mM}$ phosphate buffer solution ( $\mathrm{pH} 8.0)$ prior to the evaluation. The recovery tests for ammonium were conducted after addition of a known concentration of ammonium to the water samples.

\section{Results and Discussions}

\subsection{Optimization of an Optical Assay for Ammonium Employing the Biosensor}

The determination of ammonium in the environmental samples employing enzymatic reactions has been reported previously $[7,10]$. The applications of diaphorase coupled with tetrazolium salts, which produce highly colored formazan dyes upon NADH oxidation, have been used as chromogenic reagents for quantification of NADH as detection signal [15]. In this study, we explored the use of dual enzymes system GLDH/Diaphorase in combination with MTT for the determination of ammonium in aqueous solutions. The enzymatic reaction involved is shown in the following equations:

$$
\begin{aligned}
& \mathrm{NH}_{4}^{+}+\alpha \text {-ketoglutaratic acid }+\mathrm{NADH} \stackrel{\text { GLDH }}{\longrightarrow} \\
& \text { L-glutamate }+\mathrm{NADH}_{\text {unreacted }}+\mathrm{NAD}^{+} \\
& \mathrm{NADH}_{\text {unreacted }}+\mathrm{MTT} \stackrel{\text { Dph }}{\longrightarrow} \text { Formazan }+\mathrm{NAD}^{+}
\end{aligned}
$$

In the presence of $\mathrm{NH}_{4}^{+}$, enzymatic conversion of $\alpha$ ketoglutaric acid to L-glutamate by the immobilized GLDH requires NADH as a cofactor. In this reaction, the consumption of NADH depends on the $\mathrm{NH}_{4}{ }^{+}$concentration, which result in excess of unreacted NADH. The excess of unreacted $\mathrm{NADH}$ is then oxidized to $\mathrm{NAD}^{+}$in the presence of MTT by the Dph. When MTT accept electrons, it will be reduced to purple color of formazan. 
Figure 1(c) shows the absorption spectra of the biosensor based on stacked immobilization of GLDH and Dph in chitosan film in the presence of MTT $(0.3 \mathrm{mM}), \mathrm{NADH}$ $(0.1 \mathrm{mM}), \alpha$-ketoglutaric acid $(0.14 \mathrm{mM})$ and different concentrations of ammonium $(0.0-0.07 \mathrm{mM})$. The optimum response of the biosensor was observed at a wavelength of $565 \mathrm{~nm}$. As can be seen in Figure 1(c), at various concentrations of ammonium the color intensity of the formazan was found to decrease proportionally with the increase of the ammonium concentrations after 10 min exposure. This result indicates that the consumption of NADH is dependent on the ammonium concentration used in the reaction system.

In order to obtain optimum response of the designed biosensor, a series of experiment conditions were performed and summarized in Table 1. The effect of $\mathrm{pH}$ was investigated using phosphate and tris- $\mathrm{HCl}$ buffers covering the $\mathrm{pH}$ ranging from $6-9(50 \mathrm{mM})$. The response was obtained by measuring at respective concentrations of ammonium $(0.0,0.08$ and $0.17 \mathrm{mM}), \mathrm{NADH}$ $(0.15 \mathrm{mM}), \alpha$-ketoglutaric acid $(0.15 \mathrm{mM})$ and MTT $(0.2$
$\mathrm{mM}$ ). As summarized in Table $\mathbf{1}$ the maximum $\mathrm{pH}$ was observed at $8(50 \mathrm{mM}$ phosphate buffer) and this $\mathrm{pH}$ was used for further studies. To improve the biosensor performance, various enzyme loading and MTT concentrations were studied. The effect of Dph loading in a chitosan film (2\%) on the biosensor response was examined. Upon increasing the Dph loading, the biosensor response increased sharply to reach a maximum value. Above the loading $0.07 \mathrm{mg}$, enzyme saturation behaviour was occurred. The loading for the GLDH was based on our previous work [16]. Thus, $0.07 \mathrm{mg}$ of Dph and GLDH were used for the preparation of the biosensing film.

The effect of MTT concentrations on the sensor response was carried out by varying the concentrations between $0.05-0.50 \mathrm{mM}$ and optimum response of the biosensor was obtained at MTT concentration of $0.3 \mathrm{mM}$. Above this concentration reduction in the biosensor response was observed which probably due to the saturated of formazan complex formation on the biosensor surface. The influence of various NADH and $\alpha$-ketoglutaric acid concentrations was further explored by studying the color

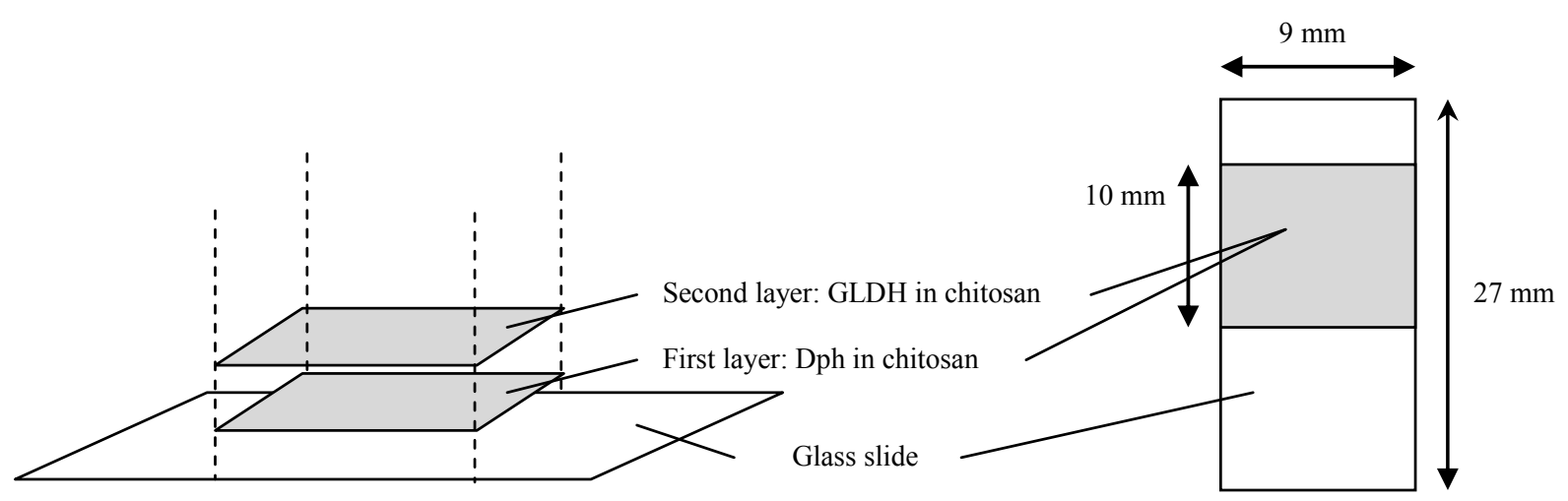

(a)

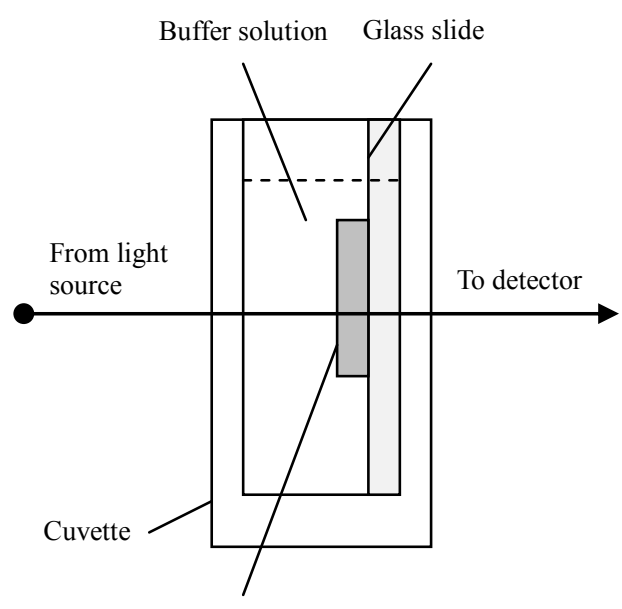

Film of Dph-Chitosan/GLDH-Chitosan

(b)

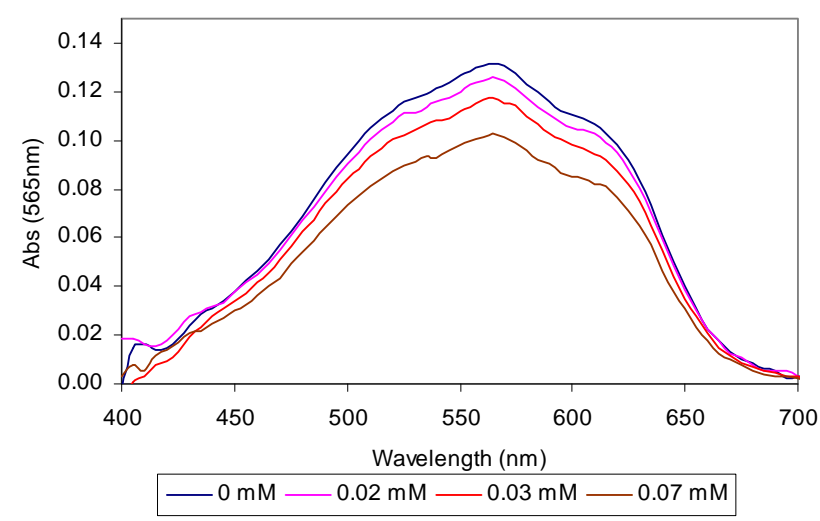

(c)

Figure 1. The process of stacked immobilization of Dph-Chitosan/GLDH-Chitosan onto a glass slide (a); the biosensor used for measurement of ammonium concentration (b); and its absorption spectra at various concentrations of ammonium (c). 
Table 1. Optimization experimental parameters.

\begin{tabular}{lcc}
\hline \multicolumn{1}{c}{ Experimental conditions } & Value range & $\begin{array}{c}\text { Optimum } \\
\text { value }\end{array}$ \\
\hline $\mathrm{pH}$ & $6.0-9.0$ & 8.0 \\
Dph loading (mg) & $0.01-0.13$ & 0.07 \\
MTT concentrations (mM) & $0.05-0.50$ & 0.30 \\
NADH concentrations (mM) & $0.05-0.30$ & 0.20 \\
$\alpha$-ketoglutaric acid concentration $(\mathrm{mM})$ & $0.05-0.30$ & 0.15 \\
\hline
\end{tabular}

formation of formazan on the surface of the sensor film. The amount of NADH in the enzyme membrane must be sufficient in order to obtain a good linear range. The response increased with increasing NADH concentration and reaches an optimum value at a concentration of 0.20 $\mathrm{mM}$. The performance of the biosensor was further evaluated by optimizing $\alpha$-ketoglutaric acid concentration ranging from $0.05-0.30 \mathrm{mM}$. The optimum concentration of $\alpha$-ketoglutaric acid was obtained at $0.15 \mathrm{mM}$. Further increase in the concentration of $\alpha$-ketoglutaric acid results the decrease in the biosensor response which, may attribute to an inhibitory effect of $\alpha$-ketoglutaric on the enzyme activity [17].

Figure 2 illustrates the response of the biosensor towards various concentrations of ammonium $(0,0.1$ and $0.25 \mathrm{mM}$ ). As shown, the response of the biosensor increased with time until $30 \mathrm{~min}$ reaction time. It can be noted that the time taken to achieve steady state response was longer. This could be due to the diffusion of analyte in the dual enzymes film was affected the sensor response [18]. Therefore, a kinetic approach was used in this study to quantify ammonium concentration where the intensity of the biosensor was decided to be measured after 10 min reaction time to obtain sufficient response.

\subsection{Analytical Application}

Figure 3 showed the dynamic response of the biosensor obtained by addition of ammonium concentrations ranging from $0.0-0.17 \mathrm{mM}$. The decreased of formazan intensity produced due to the consumptions of NADH by GLDH/Dph in the chitosan layer was proportional to the concentrations of ammonium. A linear response of the biosensor was obtained at an ammonium concentration range of $16.8-70 \mu \mathrm{M}$ (slope $\left.=0.3263, \mathrm{R}^{2}=0.9955\right)$ with the detection limit calculated to be at $11 \mu \mathrm{M}$. Although the linear response was quite narrow, the combination of enzymes and dye system improved the biosensor selectivity and simplified the determination of ammonium.

For kinetic study, the apparent Michaels-Menten constant $\left(\mathrm{K}_{\mathrm{m}}\right)$ was estimated using the Lineweaver-Burk plots. The $\mathrm{K}_{\mathrm{m}}$ gives information on the enzyme-substrate kinetics for the biosensor and the values calculated to be at $1.89 \mathrm{mM}$. The $\mathrm{K}_{\mathrm{m}}$ value determined with the present biosensor is comparable to the reported value using am- perometric detection [2], where the $\mathrm{K}_{\mathrm{m}}$ of $1.5 \mathrm{mM}$ is obtained utilizing bienzyme system (glutamate oxidase/ glutamate dehydrogenase) immobilized using poly (carbamoyl) sulfonate hydrogel. The reproducibility in the biosensor fabrication was also investigated at respective ammonium, MTT, NADH and $\alpha$-ketoglutaric acid concentrations of $0.25 \mathrm{mM}, 0.30 \mathrm{mM}, 0.20 \mathrm{mM}$ and 0.15 $\mathrm{mM}$ and it was found to be good with a relative standard deviation (RSD) of $5.46 \%(n=6)$.

The analytical performance of the developed optical ammonium biosensor has been compared with several biosensors. Characteristics such as technique of detection, biorecognition, linearity and limit of detection are compared. As shown in Table 2, the limit of detection of the present work was comparable with several techniques $[8,19]$ for the detection of ammonium.

\subsection{Interference Studies}

The response of the biosensor to the potential interferents was examined by the additions of interference substances that are possibly present in the aquatic environment such as $\mathrm{Cu}(\mathrm{II}), \mathrm{Zn}$ (II), $\mathrm{Ag}$ (I), $\mathrm{Hg}$ (II), $\mathrm{Ca}(\mathrm{II}), \mathrm{Fe}(\mathrm{II}), \mathrm{K}(\mathrm{I}), \mathrm{Cl}^{-}$and $\mathrm{NO}_{3}^{-}$. The analysis was conducted in the presence

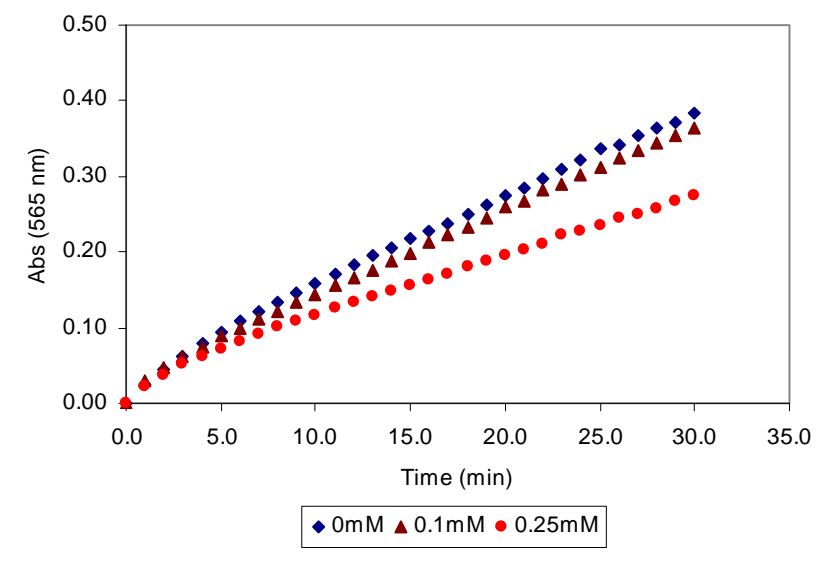

Figure 2. The response of the biosensor towards different concentrations of ammonium (0 - $0.25 \mathrm{mM})$.

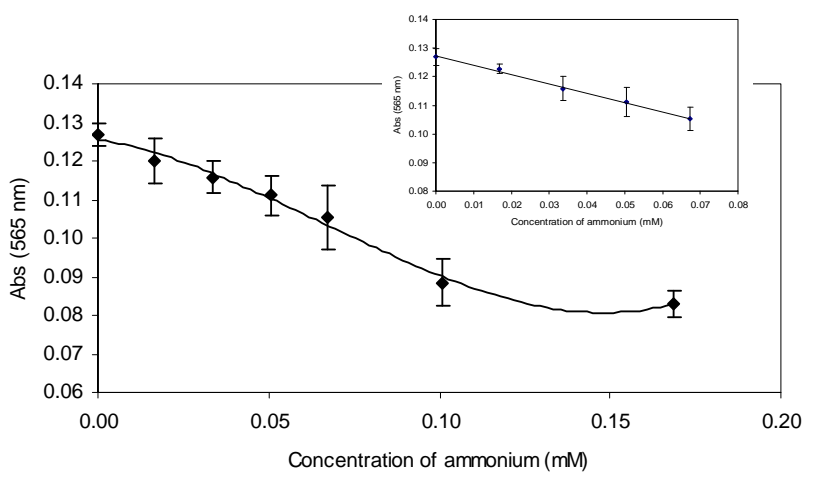

Figure 3. The dynamic response range of the biosensor towards different concentrations of ammonium $(n=3)$. 
Table 2. Performance comparison of ammonium biosensor.

\begin{tabular}{ccccc}
\hline Technique & Biorecognition & Dynamic range $(\mu \mathrm{M})$ & Limit of detection $(\mu \mathrm{M})$ & Ref. \\
\hline Amperometric & GLDH & $10-200$ & 5 & {$[3]$} \\
Amperometric & GLDH & $10-300$ & 10 & {$[8]$} \\
Fluorimetric flow assay & GLDH & $5-500$ & - & {$[9]$} \\
Amperometric & Ammonia oxidizing bacteria & $10-200$ & $>10$ & {$[19]$} \\
Continuous flow analysis & Ammonia oxidizing bacteria & $10-50$ & - & {$[20]$} \\
Optical spectrophotometric & Dph/GLDH & $16.8-70$ & 11 & Present work \\
\hline
\end{tabular}

of a known concentration of ammonium and interfering ion at a ratio of 1:10 (ammonium: $0.1 \mathrm{mg} / \mathrm{L}$, interfering ions: $1 \mathrm{mg} / \mathrm{L}$ ). Figure 4 shows the change of absorbance intensity in the presence of various interfering substances. The calculated RSD value were within the range of $\pm 5 \%$, which indicated that the ions $\mathrm{Cu}(\mathrm{II}), \mathrm{Zn}(\mathrm{II}), \mathrm{Hg}(\mathrm{II})$, $\mathrm{Ca}(\mathrm{II}), \mathrm{Fe}(\mathrm{II}), \mathrm{K}(\mathrm{I}), \mathrm{Cl}^{-}$and $\mathrm{NO}_{3}^{-}$did not show any significant interference except for $\operatorname{Ag}(\mathrm{I})$ ions appeared to cause interference (Table 3). This may be attributed to the inhibitory effect of this metal ion on the enzyme activity, particularly at high $\mathrm{Ag}(\mathrm{I})$ ion concentrations.

\subsection{Comparison of the Biosensor Response and Analysis of Spiked Real Samples}

Figure 5 presents the results of the developed biosensor compared with the indothymol method in the range of ammonium concentration of $0.0-0.15 \mathrm{mM}$. A very good agreement was observed between the biosensor and the indothymol method with slope $=0.9953$ and $r=0.9984$.

In order to evaluate the applicability of the biosensor to real sample analysis, various water samples from several fish ponds were tested. The recovery test was performed by adding a known concentration of ammonium to the sample solutions. The results from these water samples are summarized in Table 4. Both the biosensor and the indothymol methods recovered about $103 \%$ $119 \%$ and $108 \%-125 \%$ of the ammonium from the water samples, respectively. The relative standard error between indothymol method and biosensor for the determination of ammonium in the spiked water samples was about $3 \%-11 \%$.

Statistical analysis for comparing the two means concentration of ammonium determined by the biosensor and the indothymol methods were tested. The t-test applied to the real samples determined by the method described by Miller and Miller [21]. As shown in Table 4, the calculated values of $|t|$ are less than the critical value, which confirms that there is no difference between the two methods for the determination ammonium concentration at the 5\% level. Therefore, these two methods employed for the determination of ammonium in the spiked fish pond water samples were in good agreement and comparable.

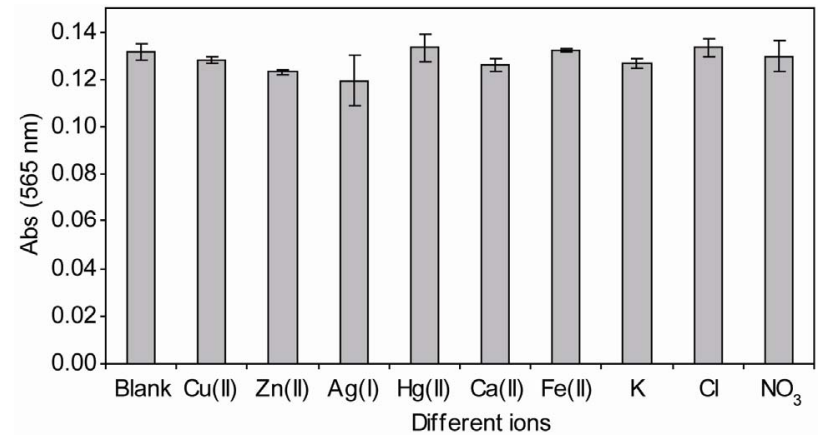

Figure 4. Effect of the biosensor to various types of interferent ions. The reaction was conducted in $50 \mathrm{mM}$ phosphate buffer solution consisting of $0.03 \mathrm{mM}$ ammonium, $0.15 \mathrm{mM} \alpha$-ketoglutaric acid, $0.3 \mathrm{mM}$ MTT and $0.2 \mathrm{mM}$ NADH, respectively $(n=3)$.

Table 3. Activity of the biosensor after reaction with different metal ions for interference study.

\begin{tabular}{ccc}
\hline Possible interferent & Concentration $(\mathrm{mg} / \mathrm{L})$ & Change of abs intensity $(\%)$ \\
\hline $\mathrm{Cu}(\mathrm{II})$ & 1.0 & +1.5 \\
$\mathrm{Zn}(\mathrm{II})$ & 1.0 & +5.0 \\
$\mathrm{Ag}(\mathrm{I})$ & 1.0 & +8.1 \\
$\mathrm{Hg}(\mathrm{II})$ & 1.0 & -2.7 \\
$\mathrm{Ca}(\mathrm{II})$ & 1.0 & +3.1 \\
$\mathrm{Fe}(\mathrm{II})$ & 1.0 & -1.7 \\
$\mathrm{~K}(\mathrm{I})$ & 1.0 & +2.5 \\
$\mathrm{Cl}^{-}$ & 1.0 & -2.6 \\
$\mathrm{NO}_{3}^{-}$ & 1.0 & +0.3 \\
\hline
\end{tabular}

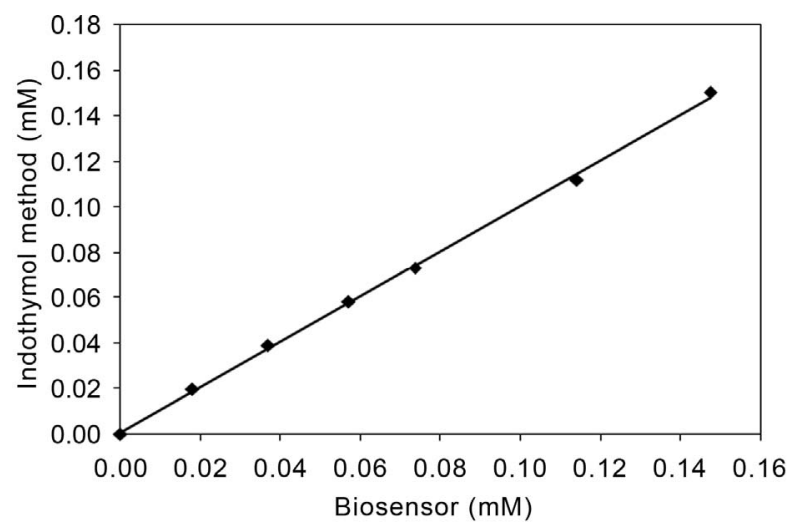

Figure 5. Relationship between the indothymol method and the developed biosensor in the determination of ammonium. 
Table 4. Determination of ammonium in spiked water samples using the indothymol method and the biosensor reported in this work.

\begin{tabular}{|c|c|c|c|c|c|c|c|}
\hline \multirow{2}{*}{ Fish pond water samples } & \multicolumn{3}{|c|}{ Indothymol method $(\mathrm{n}=3)$} & \multicolumn{3}{|c|}{ Biosensor $(n=3)$} & \multirow{2}{*}{ Calculated t-test } \\
\hline & Added (mM) & Found (mM) & Recovery $(\%)$ & Added (mM) & Found (mM) & Recovery (\%) & \\
\hline 1 & 0.037 & 0.043 & 115.0 & 0.037 & 0.039 & 103.6 & 0.50 \\
\hline 2 & 0.037 & 0.047 & 125.0 & 0.037 & 0.044 & 117.2 & 1.03 \\
\hline 3 & 0.037 & 0.042 & 110.9 & 0.037 & 0.040 & 107.8 & 0.23 \\
\hline 4 & 0.037 & 0.041 & 108.1 & 0.037 & 0.045 & 119.1 & 1.96 \\
\hline
\end{tabular}

Note: the critical value, $\mathrm{t}_{4}=2.78(\mathrm{p}=0.05)$.

\section{Conclusion}

In this study, we demonstrated a simple and rapid method for the quantitative determination of ammonium using dual enzyme system coupled with redox indicator. In this method, the color intensity of the formazan dye produced from the enzymatic reaction was found to decrease proportionally with increasing of ammonium ion concentration. The developed biosensor exhibits good sensitivity, selectivity, reproducibility, and it also provided an alternative method for analysis of ammonium.

\section{Acknowledgements}

The authors are grateful for the financial support provided by the Malaysian Government through its Ministry of Science, Technology and Innovation under Science Fund 02-03-02-SF0002.

\section{REFERENCES}

[1] F. Valentini, V. Biagiotti, C. Lete, G. Palleschi and J. Wang, "The Electrochemical Detection of Ammonia in Drinking Water Based on Multi-Walled Carbon Nanotube/Copper Nanoparticle Composite Paste Electrodes," Sensors and Actuators B: Chemical, Vol. 128, No. 1, 2007, pp. 326-333. doi:10.1016/j.snb.2007.06.010

[2] R. C. H. Kwan, P. Y. T. Hon and R. Renneberg, "Amperometric Determination of Ammonium with Bienzyme/Poly (Carbamoyl) Sulfonate Hydrogel-Based Biosensor," Sensors and Actuators B: Chemical, Vol. 107, No. 2, 2005, pp. 616-622. doi:10.1016/j.snb.2004.11.028

[3] B. Strehlitz, B. Grundig and H. Kopinke, "Sensor for Amperometric Determination of Ammonia and AmmoniaForming Enzyme Reactions," Analytica Chimica Acta, Vol. 403, No. 1-2, 2000, pp. 11-23. doi:10.1016/S0003-2670(99)00594-2

[4] K. Fukushi, H. Ito, K. Kimura, K. Yokota, K. Saito, K. Chayama, S. Takeda and S. Wakida, "Determination of Ammonium in River Water and Sewage Samples by Capillary Zone Electrophoresis with Direct UV Detection," Journal of Chromatography A, Vol. 1106, No. 1-2, 2006, pp. 61-66. doi:10.1016/j.chroma.2005.10.054

[5] Q. P. Li, J. Z. Zhang, F. J. Millero and D. A. Hansell, "Continuous Colorimetric Determination of Trace Ammonium in Seawater with a Long-Path Liquid Waveguide Capillary Cell," Marine Chemistry, Vol. 107, No. 1-2,
2005, pp. 73-85. doi:10.1016/j.marchem.2004.12.001

[6] K. T. Lau, S. Edwards and D. Diamond, "Solid-State Ammonia Sensor Based on Berthelot's Reaction," Sensors and Actuators B: Chemical, Vol. 98, No. 1, 2004, pp. 12-17. doi:10.1016/j.snb.2003.08.004

[7] A. K. Abbas, J. P. Hart, D. C. Cowell and A. Chappell, "Development of an Amperometric Assay for $\mathrm{NH}_{4}{ }^{+}$ Based on a Chemically Modified Screen-Printed NADH," Analytica Chimica Acta, Vol. 373, No. 1, 1998, pp. 1-8. doi:10.1016/S0003-2670(98)00368-7

[8] P. Bertocchi and D. Compagnone, "Amperometric Ammonium Ion and Urea Determination with Enzyme-Based Probes," Biosensors and Bioelectronics, Vol. 11, No. 1-2, 1996, pp. 1-10. doi:10.1016/0956-5663(96)83708-0

[9] R. Quiles, J. M. F. Romero, E. Fernandez and M. D. L. Castro, "Continuous Flow Assay of Ammonia in Plasma Using Immobilized Enzymes," Analytica Chimica Acta, Vol. 294, No. 1, 1996, pp. 43-47. doi:10.1016/0003-2670(94)85044-5

[10] S. Hashimoto, H. Y. Sun, A. Otsuki, S. Kawakama and M. Yokomizo, "Enzymatic Determination of Ammonia in Lake Water Using a Semi-Automatic Analyser," International Journal of Environmental Analytical Chemistry, Vol. 48, No. 3-4, 1992, pp. 155-161. doi:10.1080/03067319208027396

[11] H. Jaegfelt, A. B. C. Torstensson, L. Gorton and G. Johansson, "Catalytic Oxidation of Reduced Nicotinamide Adenine Dinucleotide by Graphite Electrodes Modified with Adsorbed Aromatics Containing Catechol Functionalities," Analytical Chemistry, Vol. 53, No. 13, 1981, pp. 1979-1982. doi:10.1021/ac00236a007

[12] J. Moiroux and P. J. Elving, "Adsorption Phenomena in the NAD ${ }^{+} / \mathrm{NADH}$ System at Glassy Carbon Electrodes," Journal of Electroanalytical Chemistry, Vol. 102, No. 1, 1979, pp. 93-108. doi:10.1016/S0022-0728(79)80033-9

[13] E. Wang, L. Zhu, L. Ma and H. Patel, "Optical Sensors for Sodium, Potassium and Ammonium Ions Based on Lipophilic Fluorescein Anionic Dye and Neutral Carriers," Analytica Chimica Acta, Vol. 357, No. 1-2, 1997, pp. 85-90. doi:10.1016/S0003-2670(97)00532-1

[14] Y. M. Martinez, R. H. Hernandez and P. C. Falco, "Improved Detection Limit for Ammonium/Ammonia Achieved by Berhelot's Reaction by Use of Solid-Phase Extraction Coupled to Diffuse Reflectance Spectroscopy," Analytica Chimica Acta, Vol. 534, No. 2, 2005, pp. 327334. doi:10.1016/j.aca.2004.11.044

[15] A. K. Sarker, H. Ukeda, D. Kawana and M. Sawamura, 
"Enzymatic Assay of Dehydrogenase Substrate Based on the Detection of Superoxide Anion," Food Research International, Vol. 34, No. 5, 2001, pp. 393-399. doi:10.1016/S0963-9969(00)00183-6

[16] N. E. Azmi, J. Abdullah, M. Ahmad, L. Y. Heng, H. Sidek and K. Nadarajah, "Biosensor Based on Glutamate Dehydrogenase Immobilized in Chitosan for the Determination of Ammonium in Water Samples," Analytical Biochemistry, Vol. 388, No. 1, 2009, pp. 28-32. doi:10.1016/j.ab.2009.02.005

[17] P. Odman, W. B. Wellborn and A. S. Bommarius, "An Enzymatic Process to $\alpha$-Ketoglutarate from L-Glutamate: the Coupled System L-Glutamate Dehydrogenase/NADH Oxidase," Tetrahedron: Assymetry, Vol. 15, No. 18, 2004, pp. 2933-2937. doi:10.1016/j.tetasy.2004.07.055

[18] B. Kuswandi, Nuriman, H. H. Dam, D. N. Reinhoud and
W. Verboom, "Development of a Disposable Mercury Ion-Selective Optode Based on Trityl-Picolinamide as Ionophore," Analytica Chimica Acta, Vol. 591, No. 2, 2007, pp. 208-213. doi:10.1016/j.aca.2007.03.064

[19] A. Bollmann and N. P. Revsbech, "An $\mathrm{NH}_{4}^{+}$Biosensor Based on Ammonia-Oxidizing Bacteria for Use under Anoxic Conditions," Sensor and Actuators B, Vol. 105, No. 2, 2005, pp. 412-418. doi:10.1016/j.snb.2004.06.030

[20] W. D. Boer, P. A. K. Gunnewiek and H. J. Laanbroek, "Ammonium-Oxidation at Low $\mathrm{pH}$ by a Chemolithotrophic Bacterium Belonging to the Genus Nitrosospira," Soil Biology Biochemistry, Vol. 27, No. 2, 1995, pp. 127-132. doi:10.1016/0038-0717(94)00157-V

[21] J. N. Miller and J. C. Miller, "Statistics and Chemometrics for Analytical Chemistry," 4th Edition, Pearson Education Limited, Essex, 2000, pp. 42-51. 